\title{
Neurologic complications of coronavirus infections
}

Avindra Nath, MD

Neurology ${ }^{\circledR}$ 2020;94:809-810. doi:10.1212/WNL.0000000000009455

In 1896, Sir William Osler ${ }^{1}$ said, "Humanity has but three great enemies: fever, famine, and war; of these by far the greatest, by far the most terrible, is fever." This rings true even today.

The newly emerged severe acute respiratory syndrome coronavirus 2 (SARS-CoV2) has stricken fear and panic among the public, health care workers, patients, politicians, and financial markets. Fear strikes the minds of the unprepared. So we must ask ourselves why have we been caught by surprise? In the recent past, there have been many major epidemics. This includes Ebola, Zika, dengue, chikungunya, acute flaccid myelitis, and H1N1 influenza, to name a few. But SARS-CoV2 is different. It struck home! And so very rapidly. It emerged in the region of Wuhan in China around December last year, and by March, every state in the United States and over a hundred countries have reported cases of the infection with deaths in all the adult age groups. The predictions are dire. The entire health care system could potentially be overwhelmed and could crumble. Signs of that are already evident in New York and Washington state. Grocery stores have empty shelves, pharmacies are running out of critical medications, and there is scarcity of personal protection equipment and ventilators.

The major clinical manifestations of the SARS-CoV2 infection are due to pulmonary complications. Although most have mild symptoms, such as fever, headache, cough, dyspnea, myalgia, and anosmia, some develop acute respiratory distress syndrome about a week into the illness, which can result in death. ${ }^{2}$ Rhabdomyolysis can be a late complication of the infection. ${ }^{3}$ The mortality rate is about $3 \%-4 \%$. Terminally, patients go into coma, which is thought to be due to hypoxia or multiorgan failure. But many unanswered questions remain. Could the headache be symbolic of viral meningitis? There is a report of detection of the virus in the CSF of 1 patient (encephalitis.info/blog/coronavirus). Does anosmia suggest involvement of the olfactory bulbs? In mouse models of coronavirus encephalitis, the virus can enter the brain transneuronally through the olfactory pathways. ${ }^{4}$ Hence, this relatively innocuous symptom could be indicative of a potentially more serious complication. Can the respiratory syndrome be due to brainstem involvement? Brain imaging and pathologic evaluation of the brain are necessary to understand the full impact of the virus. The elderly and immunocompromised patients are particularly vulnerable. Many have underlying neurologic comorbidities. Hypertension and diabetes seem to stand out as the most common comorbidities in patients with more severe manifestations of the infection. An interesting hypothesis has emerged around the use of angiotensin-converting enzyme (ACE) inhibitors to treat hypertension and diabetes to explain this phenomenon. ACE2 is the receptor for SARS-CoV2. ${ }^{5}$ The use of ACE inhibitors leads to increased expression of ACE2, making the cells more vulnerable to infection with the virus. Clinical studies are underway to test this hypothesis. ACE2 can be found on endothelial cells in the brain and can be induced in neurons, raising the possibility that strokes associated with SARS-CoV2 might be directly related to the infection, and encephalitis could be a potential complication.

There are several human coronaviruses (HCoVs). Most cause mild respiratory symptoms and resolve. However, in recent years, new coronaviruses have jumped species and infected humans with devastating consequences. Several acute neurologic syndromes have been associated with coronaviruses (table). Severe acute respiratory syndrome coronavirus 1 has been detected in the CSF of a patient with encephalitis and acute respiratory distress syndrome. ${ }^{6}$ Middle East

\author{
Correspondence \\ Dr. Nath \\ natha@ninds.nih.gov
}

MORE ONLINE

COVID-19 Resources

For the latest articles, invited commentaries, and blogs from physicians around the world

NPub.org/COVID19 
Table Acute neurologic complications of coronavirus infections

Viral meningitis

Anosmia

Encephalitis

Postinfectious acute disseminated encephalomyelitis

Postinfectious brainstem encephalitis

Guillain-Barré syndrome

Myositis

Acute necrotizing hemorrhagic encephalopathy

respiratory syndrome coronavirus can cause a severe acute disseminated encephalomyelitis and a vasculopathy. ${ }^{7}$ A postinfectious brainstem encephalitis and Guillain-Barré syndrome have also been described. ${ }^{8} \mathrm{HCoV}-\mathrm{OC} 43$ can also cause an acute disseminated encephalomyelitis with lesions scattered throughout the brain, cerebellum, and spinal cord. ${ }^{9}$ Immunocompromised individuals are particularly vulnerable. A fatal encephalitis can occur in immunocompromised patients with $\mathrm{HCoV}-\mathrm{OV} 43$. In these patients, infection of neurons has been demonstrated at autopsy. ${ }^{10} \mathrm{~A}$ similar concern has been raised with SARS-CoV2. Many patients with autoimmune syndromes such as multiple sclerosis, myasthenia gravis, neuromyelitis optica, or sarcoidosis are on a wide variety of immunosuppressive therapies. Drugs that cause systemic immune suppression wound be of concern. It might be prudent for such patients to take extra precautions to prevent exposure to the virus and to reevaluate the dosages of the medications. However, it may not be advisable to take them off treatment because the underlying illness will surely re-emerge, causing serve manifestations in many. With restrictions on travel being imposed and all elective patient appointments being canceled, there is an urgent cry for teleneurology as a substitute for faceto-face interactions with patients. However, to make this work, we need to develop a centralized system to license physicians in the entire country and not in each state individually.

Seropositivity for coronaviruses has been reported in a variety of neurologic disorders, which include encephalitis, ${ }^{11}$ optic neuritis, ${ }^{12}$ multiple sclerosis, ${ }^{13}$ and Parkinson disease. ${ }^{14}$ Virus has also been isolated from the CSF and brain of patients with multiple sclerosis. ${ }^{15}$ Viruses implicated include HCoV-229E, $\mathrm{HCoV}-293$, and HCoV-OC43. But the significance of these findings is not clear because these viruses are very prevalent and their causative role in these diseases has not been established.

In the past century, we have made tremendous progress in the prevention, diagnosis, and treatment of diseases. We can dissolve clots in the carotids, we can fix mutated genes before they can cause harm, and we can image the brain and its networks with exquisite precision, yet we have been brought down to our knees by the tiniest of organisms, about $60 \mathrm{~nm}$ in size. We need to retool and rethink how we train physicians in the practice of neurology and physician scientists in the academic neurology and how we prioritize drug development for neurologic diseases, and we need to enable academia and pharma to develop treatments not based on profits but rather on costs to humanity. Although we all recognize the hundreds of viruses that can cause encephalitis and result in devastation to large populations, we have no treatment for any of these organisms except for herpes encephalitis. It is time for us to recognize that we are facing a crisis in neurology. ${ }^{16}$ The time to take action is now.

\section{Study funding}

This work is supported by the intramural funds from the National Institute of Neurological Disorders and Stroke at the NIH, ZIA NS003130.

\section{Disclosure}

The author reports no disclosures. Go to Neurology.org/N for full disclosures.

\section{Publication history}

Received by Neurology March 23, 2020. Accepted in final form March 24, 2020.

\section{References}

1. Osler W. The study of the fevers of the South. JAMA 1896;26:999-1004.

2. Zhou F, Yu T, Du R, et al. Clinical course and risk factors for mortality of adult inpatients with COVID-19 in Wuhan, China: a retrospective cohort study. Lancet 2020;395:1054-1062.

3. Jin M, Tong Q. Rhabdomyolysis as potential late complication associated with 2019 novel coronavirus disease. Emerg Infect Dis Epub 2020 March 20.

4. Dubé M, Le Coupanec A, Wong AHM, Rini JM, Desforges M, Talbot PJ. Axonal transport enables neuron-to-neuron propagation of human coronavirus OC43. J Virol 2018;92:e00404-e00418.

5. Yan R, Zhang Y, Li Y, Xia L, Guo Y, Zhou Q. Structural basis for the recognition of the SARS-CoV-2 by full-length human ACE2. Science 2020;367:1444-1448.

6. Hung EC, Chim SS, Chan PK, et al. Detection of SARS coronavirus RNA in the cerebrospinal fluid of a patient with severe acute respiratory syndrome. Clin Chem 2003;49:2108-2109.

7. Arabi YM, Harthi A, Hussein J, et al. Severe neurologic syndrome associated with Middle East respiratory syndrome corona virus (MERS-CoV). Infection 2015;43: 495-501.

8. Kim JE, Heo JH, Kim HO, et al. Neurological complications during treatment of Middle East respiratory syndrome. J Clin Neurol 2017;13:227-233.

9. Yeh EA, Collins A, Cohen ME, Duffner PK, Faden H. Detection of coronavirus in the central nervous system of a child with acute disseminated encephalomyelitis. Pediatrics 2004;113:e73-e76.

10. Morfopoulou S, Brown JR, Davies EG, et al. Human coronavirus OC43 associated with fatal encephalitis. N Engl J Med 2016;375:497-498.

11. Li Y, Li H, Fan R, et al. Coronavirus Infections in the central nervous system and respiratory tract show distinct features in hospitalized children. Intervirology 2016;59: 163-169.

12. Dessau RB, Lisby G, Frederiksen JL. Coronaviruses in spinal fluid of patients with acute monosymptomatic optic neuritis. Acta Neurol Scand 1999;100:88-91.

13. Salmi A, Ziola B, Hovi T, Reunanen M. Antibodies to coronaviruses OC43 and 229E in multiple sclerosis patients. Neurology 1982;32:292-295.

14. Fazzini E, Fleming J, Fahn S. Cerebrospinal fluid antibodies to coronavirus in patients with Parkinson's disease. Mov Disord 1992;7:153-158.

15. Burks JS, Devald BL, Janovsky LD, Gerdes JC. Two coronaviruses isolated from central nervous system tissue of two multiple sclerosis patients. Science 1980;209: 933-934.

16. Nath A. Neuroinfectious diseases: a crisis in neurology and a call for action. JAMA Neurol 2015;72:143-144. 


\title{
Neurology
}

\section{Neurologic complications of coronavirus infections \\ Avindra Nath \\ Neurology 2020;94;809-810 Published Online before print March 30, 2020 \\ DOI 10.1212/WNL.0000000000009455}

This information is current as of March 30, 2020

\begin{abstract}
Updated Information \& Services

including high resolution figures, can be found at: http://n.neurology.org/content/94/19/809.full

References

This article cites 15 articles, 4 of which you can access for free at: http://n.neurology.org/content/94/19/809.full\#ref-list-1

Citations

This article has been cited by 9 HighWire-hosted articles: http://n.neurology.org/content/94/19/809.full\#\#otherarticles

Subspecialty Collections

This article, along with others on similar topics, appears in the following collection(s):

Risk factors in epidemiology

http://n.neurology.org/cgi/collection/risk_factors_in_epidemiology

Viral infections

http://n.neurology.org/cgi/collection/viral_infections

Permissions \& Licensing

Information about reproducing this article in parts (figures,tables) or in its entirety can be found online at:

http://www.neurology.org/about/about_the_journal\#permissions

Reprints

Information about ordering reprints can be found online:

http://n.neurology.org/subscribers/advertise
\end{abstract}

Neurology ${ }^{\circledR}$ is the official journal of the American Academy of Neurology. Published continuously since 1951, it is now a weekly with 48 issues per year. Copyright (C 2020 American Academy of Neurology. All rights reserved. Print ISSN: 0028-3878. Online ISSN: 1526-632X.

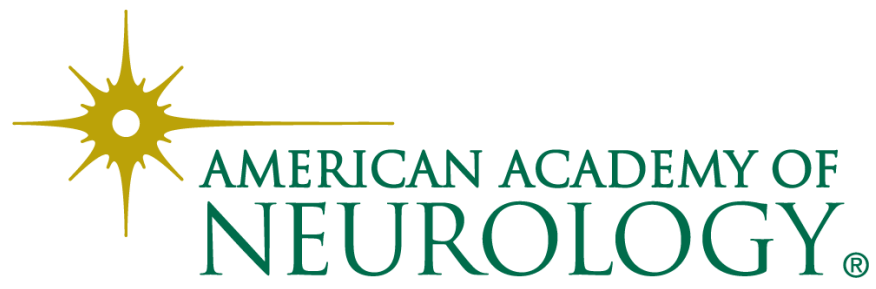

